\title{
Optimalization of DNA isolation from oral epithelial mucous cell with smear method
}

\author{
Saskia L. Nasroen*, Ani Melani Maskoen**, Agus Nurwiadh* \\ *Department of Oral and Maxillofacial Surgery Faculty of Dentistry Universitas Padjadjaran \\ Hasan Sadikin Hospital-Bandung, West Java, Indonesia \\ **Department of Oral Biology Faculty of Dentistry Universitas Padjadjaran
}

\begin{abstract}
Deoxyribonucleic acid (DNA) is a genetic material which are found in all living organisms. On the human cell or eukaryotes cell, the DNA is found in the nucleus cell and the mitochondria. The DNA arrangement on each cell in human body is the same, that is why, for the analysis meaning, DNA can be isolated from any cell in the body. The source of DNA to be analyzed usually coming from blood sample by injection method, such a way resulting in pain and bringing about constraint. Therefore, a study was carried out to look for an alternative of DNA isolation. The aim of this experimental study was to get an optimal DNA isolation method by using oral mucous smear method with a purpose to get a quick and easy DNA isolation. The investigation materials were in the form of samples which were taken from the oral epithelial mucous cells out of three different subjects. The epithelial cells were obtained by the oral mucous smear method which in variation of two, four and six times of smear applications, respectively. The DNA was then isolated using buffer extraction method. The concentrations of DNA were measured by using ultraviolet spectrophotometer at $260 \mathrm{~nm}$ wavelength. The results of DNA isolation were analyzed by Polymerase Chain Reaction (PCR) technique. The optimal DNA isolation could be analyzed by PCR technique. The experimental results shows that from three different subjects of study, DNA can be isolated optimally by oral mucous smear method with six times of smear applications.
\end{abstract}

Key words: Deoxyribonucleic acid, epithelial cell, oral mucous smear method, DNA isolation

\section{INTRODUCTION}

All genetic materials are stored in 23 pairs of chromosomes with each chromosome comprises very long molecule chains and are stored in dense and solid condition. This molecule is called DNA. DNA is a straight polymer of nucleotide which can be found in eukaryotic and mitochondria cells' cores. All cells of the same individual have the same number of nucleotide molecules and the same settlement in the chromosome of each cell. ${ }^{1,2}$
Mutation in DNA chain, precisely in the gen that codes protein, which plays a role as a controller of cell growth, may be the etiology of ferocious tumor. ${ }^{2-4}$ DNA mutation in ferocious tumor occurs before those ferocious tumor's cells grow and make tissue lesion. ${ }^{3,4}$ Consequently, if DNA mutation in that gen can be detected early, uncontrolled cells growth can be hindered.

Based on the survey result held in 1992, ferocious tumor is one of the top ten death causes in Indonesia. ${ }^{5}$ In dentistry, ferocious tumor in oral 
which is commonly found is epidermoid carcinoma. ${ }^{6}$ Death by ferocious tumor is commonly caused by patients themselves who are late visiting doctors. Fast and accurate diagnosis in ferocious tumor can be very helpful to prevent death. Laboratory diagnosis commonly taken for ferocious tumor is hispatologic and cytologic by biopsy and cytologic smear. Biopsy action takes rather long time and may give a trauma because the tissue taking procedure is done invasively. But the same condition does not happen in cytologic smear method, the procedure does not give a trauma or pain..$^{7,8}$

DNA analysis technology can be used for tracing various genetic diseases caused by DNA mutation, DNA delesion, and also for detecting ferocity. ${ }^{9}$ DNA analysis that is commonly conducted for those cases are Polymerase Chain Reaction (PCR), Single Strand Conformation Polymorphism (SSCP), Restriction Fragment Length Polymorphism (RFLP) techniques, DNA sequencing, etc. In applying those technologies, the first thing to do is isolating DNA and tissue. $2,9,10$

DNA isolation can be done by extracting DNA from many sources such as blood cell, hair cell, epithelial cell or even other body cells since every cell in a human body has the same chromosomes construction or the same gen. ${ }^{10,11}$

So far, DNA isolation is conducted by taking sample of patient's blood through injection, but that kind of procedure is not really comfortable since not all people are willing or easy to have their blood taken. Based on the condition, the writers are eager to find out another way for sample taking procedure by oral mucous smear method. Oral mucous smear is a part of cytology smear, when it is compared to injection, it gives some advantages such as painless, not invasive, and easy to conduct. ${ }^{8,12,13}$

The aim of the research is to get an optimum DNA isolation procedure by oral mucous smear; to get an easy and quick DNA isolation method in diagnosing a DNA mutation.

\section{MATERIALS AND METHODS}

There were three subjects in this research; three students Faculty of Dentistry Universitas Padjadjaran. The DNA of every subject was taken from the epithel cell of buccal mucous through twice, four times, and six times smeared. After conducting the smeared, the DNA isolation was held by dapar extraction method.

The research used laboratory descriptive method by isolating DNA from the epithel cell of oral mucous by oral mucous smear method. The research procedure was divided into four parts. The first was the procedure for DNA isolation, next was measurement of DNA concentration and purity by Ultra Violet Spectrophotometer, PCR and the last was the procedure for DNA electrophoresis.

\section{DNA isolation}

The DNA isolation was conducted based on extraction dapar method. Mucous smear was conducted to each buccal mucous of each subject by using wood spatula (ice cream stick) which had been wetted by Phosphate Buffer Saline (PBS). Each of the smeared was inserted into a $15 \mathrm{ml}$ centrifugal Tube for each subject (each tube was marked tube I, II, and III). Tube I for twice smeared, Tube II for four times smeared, Tube III for six times smeared. The tubes were given a centrifugal movement in $3000 \mathrm{rpm}$ speed for 10 minutes. The supernatant of all tubes were excreted and let it has some remains, the pellet of each tube was mixed with the supernatant remain. Each of the mixture from every tube was moved to eppendorf tube and marked with the same mark as the tube before. $30 \mu \mathrm{l}$ dapar extraction solution was then added into each eppendorf tube. After that, pellet was broken by micropipette chip and incubated in $40^{\circ} \mathrm{c}$ temperature in the water bath overnight. The next day, $1.3 \mu \mathrm{L}$ EDTA was added into each eppendorf tube for $0.25 \mathrm{mM}$, and then boiled in $100^{\circ} \mathrm{C}$ temperature for 10 minutes in the water bath. The next step, all tubes were cooled in room temperature. All tubes were given a centrifugal movement in $15.000 \mathrm{rpm}$ speed for 5 minutes in $4^{\circ} \mathrm{C}$ temperature. The supernatant occurred was the result from the DNA isolation. Next, measurement of DNA concentration and purity based on wave length by using Ultra Violet Spectrophotometer was conducted.

\section{Measurement by using ultra violet spectro- photometer}

Ultra Violet Spectrophotometer equipment was turned on and adjusted in Optical Density (OD) $260 \mathrm{~nm}$ to measure DNA concentration and in $280 \mathrm{~nm}$ to measure protein concentration. Purity 
was indicated based on the comparison of DNA and protein concentrations.

\section{Polymerase Chain Reaction (PCR)}

PCR beads, Aquabides sterile $x \mu l$, Primer A 40 pmol $1 \mu \mathrm{l}$, Primer B 40 pmol $1 \mu \mathrm{l}$, DNA sample y $\mu \mathrm{l}$, and reaction amount $25 \mu \mathrm{l}$ were consecutively poured into special tube. Primer $A$ (5'CAATGTACTATGCCTCCTTGCACC3') and primer B (5'GAGTCAAGGCTGAGAAGATGCAGGA3') were normal primer B-globin.

The aquabides and DNA sample volume depended on the result of DNA concentration and purity measurement. Even though, theoretically, the PCR technique was very sensitive in which only one DNA that could be analyzed. ${ }^{14}$ But empirically, researchers concluded that the best minimum DNA concentration for analysis using PCR technique was $200 \mathrm{ng} / \mu \mathrm{l}$ with purity $1.8-2 .{ }^{8,14}$

The mixture in the PCR tubes were vortexed and given a centrifugal movement. All the PCR tubes were put into Thermal Cycler that had been deprogrammed; the beginning of denaturation was in temperature $93^{\circ} \mathrm{C}$ for 2 minutes, the profile of each cycle was denaturated in temperature $93^{\circ} \mathrm{C}$ for 3 minutes, annealing (primer attachment) was in temperature $65^{\circ} \mathrm{C}$ for 1 minute, extension was in temperature $72^{\circ} \mathrm{C}$ for 1.5 minute, the number of cycle was 29 , the last was given extra extension for 3 minutes. The result of the PCR was electrophoresised in agarose gel $1 \%$.

\section{DNA electrophoresis}

The PCR result was then electrophoresised in agarose $1 \%$. The DNA strands image was observed and the image was captured.

\section{RESULTS}

The DNA isolation result based on DNA concentration and purity measured by Ultra Violet Spectrophotometer of each subject can be seen in Table 1, Table 2, and Table 3. In each Table, tube I for twice smeared, tube II for four times smear, and table III for six times smear.

The DNA concentration was got from multiplication between DNA absorption in OD $260 \mathrm{~nm}$ and $50 \mathrm{ng} / \mu \mathrm{l}$ (absorption in OD $260 \mathrm{~nm}=$ 1 equivalent with $50 \mathrm{ng} / \mu \mathrm{l}$ ) and it was multiplied with the amount of DNA thinning (in this research, the DNA sample was thinned for 2000 times).

The DNA isolation result of subject I, II, and

Table 1. DNA isolation result of subject I

\begin{tabular}{ccccc}
\hline Tube & $\begin{array}{c}\text { DNA absorption } \\
(\text { OD } 260 \mathrm{~nm})\end{array}$ & $\begin{array}{c}\text { Protein absorption } \\
(\text { OD } 280 \mathrm{~nm})\end{array}$ & $\begin{array}{c}\text { DNA purity } \\
\text { (OD DNA/OD protein) }\end{array}$ & DNA concentration \\
\hline I & 0,221 & 0,169 & 1,31 & $2210 \mathrm{ng} / \mu \mathrm{l}$ \\
II & 0,218 & 0,168 & 1,29 & $2180 \mathrm{ng} / \mu \mathrm{l}$ \\
III & 0,235 & 0,182 & 1,29 & $2350 \mathrm{ng} / \mu \mathrm{l}$ \\
\hline
\end{tabular}

Table 2. DNA isolation result of subject II

\begin{tabular}{ccccc}
\hline Tube & $\begin{array}{c}\text { DNA absorption } \\
(\text { OD } 260 \mathrm{~nm})\end{array}$ & $\begin{array}{c}\text { Protein absorption } \\
(\text { OD } 280 \mathrm{~nm})\end{array}$ & $\begin{array}{c}\text { DNA purity } \\
\text { (OD DNA/OD protein) }\end{array}$ & DNA concentration \\
\hline I & 0,010 & 0,007 & 1,43 & $100 \mathrm{ng} / \mu \mathrm{l}$ \\
II & 0,017 & 0,009 & 1,65 & $170 \mathrm{ng} / \mu \mathrm{l}$ \\
III & 0,020 & 0,012 & 1,67 & $200 \mathrm{ng} / \mu \mathrm{l}$ \\
\hline
\end{tabular}

Table 3. DNA isolation result of subject III

\begin{tabular}{ccccc}
\hline Tube & $\begin{array}{c}\text { DNA absorption } \\
(\text { OD } 260 \mathrm{~nm})\end{array}$ & $\begin{array}{c}\text { Protein absorption } \\
(\text { OD } 280 \mathrm{~nm})\end{array}$ & $\begin{array}{c}\text { DNA purity } \\
\text { (OD DNA/OD protein) }\end{array}$ & DNA concentration \\
\hline I & 0,020 & 0,015 & 1,33 & $200 \mathrm{ng} / \mu \mathrm{l}$ \\
II & 0,022 & 0,021 & 1,05 & $220 \mathrm{ng} / \mu \mathrm{l}$ \\
III & 0,029 & 0,020 & 1,45 & $290 \mathrm{ng} / \mu \mathrm{l}$ \\
\hline
\end{tabular}




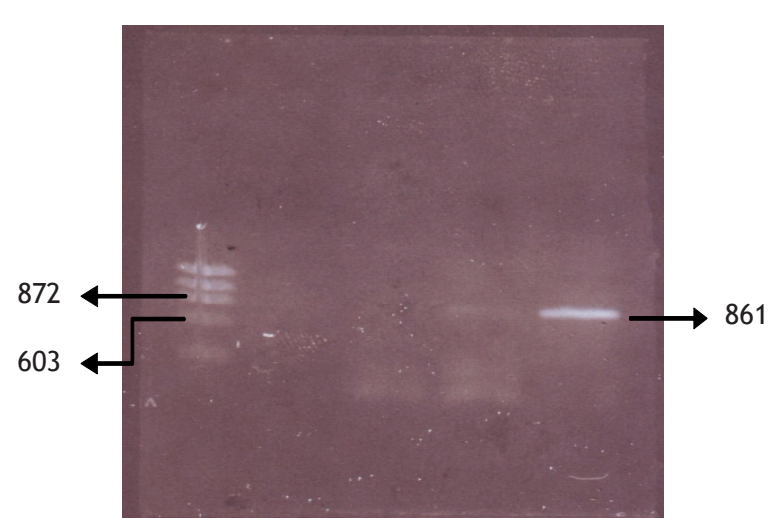

Figure 1. The PCR result of subject I which is electrophoresised in agarose 1\%; Column 1: Alkali measurement marker Lambda DNA ФX174 Haelll; Column 2: PCR result from twice smeared DNA template (Tube I); Column 3: Four times smeared (Tube II); Column 4: PCR result from six times smeared DNA template (Tube III); Column 5: DNA positive control.

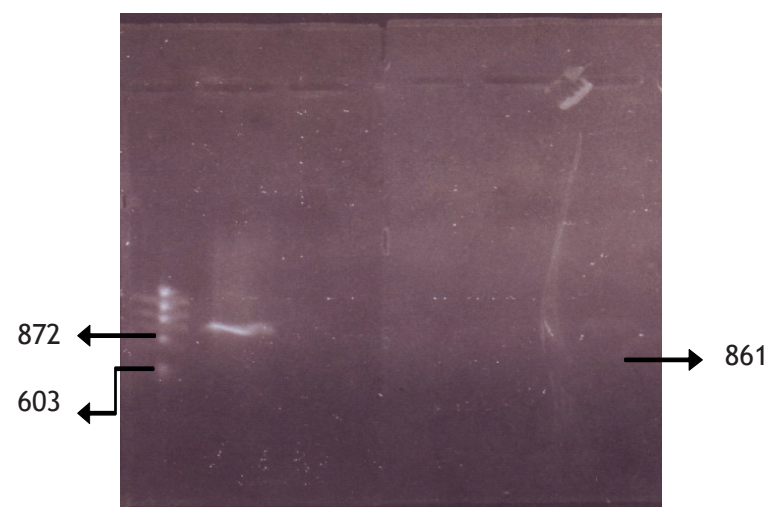

Figure 2. The PCR result of subject II ; Column 1: Alkali measurement marker Lambda DNA ФX174 Haelli; Column 2: DNA positive control; Column 3: DNA negative control; Column 4: PCR result from twice smeared DNA template (Tube I); Column 5: Four times smeared (Tube II); Column 6: Six times smeared (Tube III).

III were amplified using PCR technique. The result was electrophoresised in agarose gel $1 \%$ with ethydium bromide coloring and then visualized under Ultra Violet Transluminator and photo imaging was conducted. The PCR result image which had been electrophoresised in agarose gel $1 \%$ for each subject is displayed in Figure 1, Figure 2 , and Figure 3 . In each figure, the $1^{\text {st }}$ column shows the alkali measurement marker that is cut plasmid ФX174 using restriction enzyme Haell (lambda DNA ФX174 HaellI) so it produces DNA fragments for 1353 pairs of alkali (pb), $1078 \mathrm{pb}$, $872 \mathrm{pb}, 603 \mathrm{pb}$ and $310 \mathrm{pb}$. In each figure, the amplified DNA strands by PCR technique will be displayed in measurement $861 \mathrm{pb}$ which is placed

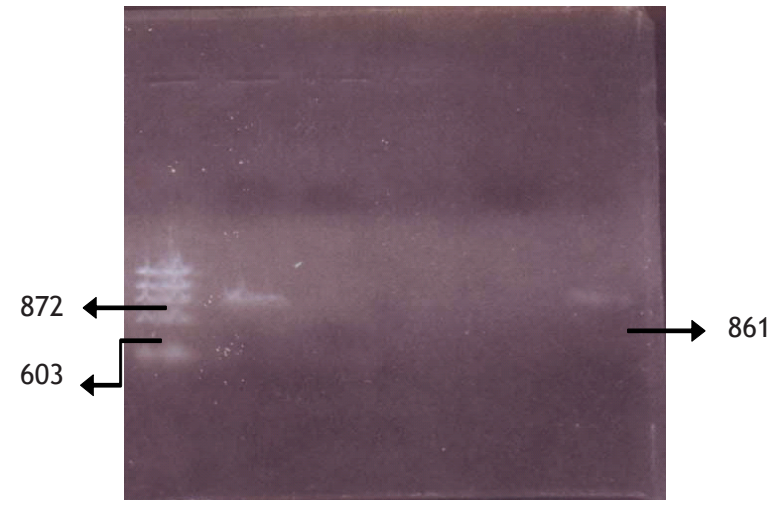

Figure 3. The PCR result of subject III; Column 1: Alkali measurement marker Lambda DNA $\Phi$ X174 Haelll; Column 2: DNA positive control; Column 3: DNA negative control; Column 4: PCR result from twice smeared DNA template (Tube I); Column 5: Four times smeared DNA template (Tube II); Column 6: Six times (Tube III).

between DNA measurement marker XX174 Haell $872 \mathrm{pb}$ dan $603 \mathrm{pb} .861 \mathrm{pb}$ is the measurement that is produced from the use of primer B-globin.

\section{DISCUSSION}

Table 1 shows the DNA concentration from DNA isolation result of subject I. The result shows the highest concentration is in tube III with six times smeared for $2350 \mathrm{ng} / \mu \mathrm{l}$, but the biggest DNA purity to protein is in Table I with twice smeared for 1,31. A conclusion can be drawn that the number of smear affects DNA concentration since the bigger number of smear, the more mucous epithel cell will be got. But the DNA purity to protein is not affected by the number of epithel cells, as seen in tube I which has the highest purity. Normally, DNA purity based on ratio between DNA absorption in OD $260 \mathrm{~nm}$ and protein absorption in OD $280 \mathrm{~nm}$ is approximately around 1.8 to $2 .{ }^{14}$ The ratio more than 2 shows the existence of RNA while the ratio less than 1.8 indicates the existence of protein or other contaminant. ${ }^{14}$ DNA purity of all tubes in the subject is very low that is below 1.8 which means the DNA solution of all tubes is contaminated by protein or other contaminant.

Purity as the result of DNA isolation can be influenced by the DNA isolation method used. This research used the DNA isolation method without DNA purification phase which usually uses phenol chloroform. ${ }^{8}$ Other factor that may cause DNA isolation is less pure is imperfect cell wall breaking with dapar extraction during DNA isolation method. 
It happens because the used protein- $K$ enzyme is damaged and cannot break the cell wall protein or other proteins which form DNA. However, when analyzing DNA using PCR technique, DNA purity is not necessarily needed since the reaction in PCR technique is quite sensitive. ${ }^{14} \mathrm{Next}$, to find out if the DNA isolation result is optimum enough, analysis using PCR technique needs to be conducted. If DNA can be amplified using this technique, it means the DNA isolation is optimum enough and successful.

The analysis result with optimum PCR technique describes as DNA strand with certain alkali length. In Figure 1, the clearest image of DNA strands is seen in column 4 , this means the most optimum analysis result with PCR technique is in tube III with six times smeared with the highest DNA concentration, $2350 \mathrm{ng} / \mu \mathrm{l}$. in column 3 (four times smeared), the DNA strand image is very thin and almost invisible, and in column 2 (twice smeared) is invisible.

Table 2 shows the DNA concentration from DNA isolation result of subject II. It is seen that the highest concentration is in tube III with six times smeared, that is $200 \mathrm{ng} / \mu \mathrm{l}$. The highest purity is in tube III as well that is 1.67 . In subject II, the DNA concentration increase is followed by the DNA purity increase even though DNA purity to protein is not affected by the number of epistle cells got. ${ }^{8,14}$ Like in subject I, the DNA purity from all tubes of subject II is below 1.8 which means the DNA solution of all tubes is contaminated by protein or other contaminants. ${ }^{8}$

The analysis result with PCR technique in Figure 2 is displayed in column 4,5 , and 6 . The optimum analysis result with PCR technique is seen in column 6 which describes the clearest DNA strand image is in tube III with six times smeared with the highest DNA concentration for $200 \mathrm{ng} / \mu \mathrm{l}$. Table 3 shows the DNA concentration from DNA isolation result of subject III. It is seen that the highest concentration is in tube III with six times smeared for $290 \mathrm{ng} / \mu \mathrm{l}$ and the highest DNA purity is in tube III as well for 1.45 . In subject III, the lowest DNA purity is in tube II with four times smeared for 1.05 and is lower than the DNA purity in tube I with twice smeared for 1.33 . This shows that DNA purity to protein is not affected by the number of mucous epithel cell got, like in subject I. In subject I and II, the DNA purity of all tubes of subject III is below 1.8 and keeps indicating the protein or other contaminants contamination. The analysis result with PCR technique in Figure 3 is displayed in column 4,5 , and 6 . The optimum analysis result with PCR technique is described by the clearest DNA strand image in column 6 of tube III with six times smeared with the highest concentration for $290 \mathrm{ng} / \mu \mathrm{l}$. Quite big difference of DNA concentration, primarily the DNA concentration difference between subject II and subject III, is probably caused by the pressure difference during conducting oral mucous smear.

There are many factors that affect the amplification success of PCR technique. One of them is the effect of impurity of DNA isolation result. Impurity of DNA isolation result is caused by the existence of other contaminants else than protein. It may be some inhibitor substances that disturb tag polymerase enzyme work of PCR technique in stringing up DNA alkali during DNA time extension. ${ }^{8}$ These inhibitor substances are detergent, phenol, EDTA, proteinase- $K$, and many more. ${ }^{8,14}$ This can be overcome by extending the time and temperature in denaturation process of PCR technique by incubating DNA isolation sample for 5 minutes in temperature $95^{\circ} \mathrm{C}$. The time and temperature can be got by choosing the PCR program that will be used. ${ }^{14}$ Consequently, in DNA isolation phase, inhibitor substances are used and PCR program choice must be accurate. Besides, with big number of smeared it is possible to get contaminants free DNA, so amplification success with PCR technique is very possible even though the DNA purity is low (below 1.8) as indicated in this research.

\section{CONCLUSION}

Based on the result, it can be concluded that the optimum DNA isolation result can be got by oral mucous smear method for six times smeared.

\section{REFERENCES}

1. Schumm DE. Essentials of biochemistry. $1^{\text {st }}$ ed. Ohio: Davis FA Co.; 1992.

2. Watson JD. Molecular biology of the gene. $5^{\text {th }}$ ed. California: Cummings Publishing Co. Inc; 2004. p. 98-112. 
3. Lewin B. Genetics V. $2^{\text {nd }}$ ed. New York: Oxford University Press; 1995.

4. Departemen Kesehatan RI. Profil kesehatan Indonesia. Jakarta: Pusat Data Kesehatan; 1996.

5. Mitchell L, Mitchell DA. Oxford handbook of clinical dentistry. New York: Oxford University Press; 1994.

6. Robbins SL, Kumar V. Buku ajar patologi I. Edisi ke-4. Jakarta: EGC; 1987.

7. Colby DS. Biochemistry: A synopsis. $4^{\text {th }}$ ed. California: Lange Medical Publications; 1992.

8. Peters P. Biotechnology: a guide to genetic engineering. United States: Wm. C. Brown Publishers; 1993.

9. Walker AH, Najarian D, White DL, Jaffe JM, Kanetsky PA, Rebbeck TR. Collection of genomic DNA by buccal swabs for polymerase chain reaction-based biomarker assays. Environmental Health Perspective; 1999;107(7):517-20.

10. Innis MA. PCR protocols: A guide to method and applications. San Diego, California: Academic Press; 1990.

11. Kumar V, Abbas AK, Fausto N. Robbins and Cotran: pathologic basis of disease. $7^{\text {th }}$ ed. Elsevier Saunders; 2005. p. 147-150.

12. Blackburn GM, Gait MJ. Nucleic acids in chemistry and biology. $2^{\text {th }}$ ed. New York: Oxford University Press; 1996.

13. Taqman SNP. Genotyping assay protocol from applied biosystems rev. 06/2004. [cited 17 Jul, 2009]. Available from:http//www. molegenetics.com.

14. Madrekar P, Flanagan L. Tereba A. Extraction and isolation of DNA from blood cards and buccal swabs in a 96-well format. Promega Corporation; 2003. p. 1-4. 